\title{
Studies of the Effect on the Haematology and Immuno-System of Clarias gariepinus Fed Graded Levels of Ocimum gratissmum as Feed Additive
}

\author{
Ekelemu Jerimoth Kesena \& Maroh Eseoghene \\ Department of Fisheries, Delta State University, Asaba Campus, Asaba-Nigeria \\ jerimothekelemu@yahoo.com
}

\begin{abstract}
Varying levels of Ocimum gratissimum were added to the diet of juveniles of Clarias gariepinus to ascertain its effect on the haematological profile of experimental fish. The study which lasted for 4 months was conducted using 15 concrete tanks of dimension $1 \mathrm{~m} \times 1 \mathrm{~m} \times 1 \mathrm{~m}$. One hundred and fifty juveniles of C.gariepinus used were acclimated for three days and distributed in 10s per tank which were grouped in triplicates, to form five treatments (1 - 5). Treatment 1, served as the control. The diets contained $0 \mathrm{~g}, 10 \mathrm{~g}, 20 \mathrm{~g}, 30 \mathrm{~g}$, and $40 \mathrm{~g}$ of $\mathrm{O}$. gratissimum per $\mathrm{kg}$ of $2 \mathrm{~mm}$ Coppens feed and labeled Diets 1 - 5 respectively. Fishes were fed rations of $3 \%$ body weight twice daily, with diets having corresponding numbers with the tanks. Blood samples were taken from one fish in each treatment at the end of the culture period to determine the blood quality of the fish in each treatment. Data collected were subjected to correlation analysis, one way analysis of variance and means were separated using Duncans multiple range test. C. gariepinus fed $10 \mathrm{~g}$ inclusion of $O$. gratissimum performed better haematologically with an increase in Red Blood cell, White Blood Cell, Plasma protein, and Mean Corpuscular Haemoglobin Concentration. It is therefore concluded that the optimum level of inclusion of $O$. gratissimum to achieve improved blood quality and boost immunity is $10 \mathrm{~g} / \mathrm{kg}$ of feed.
\end{abstract}

Keywords: Ocimum gratissimum,Clarias gariepinus, immunity.

\section{INTRODUCTION}

Catfish (Clariidae) is very popular in Nigeria due to its culturable attributes which has endeared it to many fish farmers (FAO, 2004). Expansion and growth of the aquaculture industry in Nigeria, has been slow due to challenges faced by fish farmers. These problems include lack of feed and quality fish seed for stocking. Due to the growing concern over the discovery of the side effects in using synthetic drugs in medicare, there is a renewed interest in the use of organic materials from plants in fish culture and care.

In recognition of the value of traditional medical systems, and the identification of medicinal plant from indigenous pharmacopoeias, which have significant healing powers, medicinal plants has contributed immensely to healthcare in Nigeria (John et al,2000). As a result the search for other protein sources in aqua feeds has gained much recognition (Ali et al., 2003; Erdal et al., 2004; Adewolu, 2008). Accordingly, protein sources of leaf meal origin such as duckweed have been given much attention as replacement for fish meal (Hassan and Edwards, 1992; Leng, et al., 1995; Erdal et al., 2004). Other examples of plant protein sources are alfalfa meal (Ali et al., 2003) and also potato leaf meal (Adewolu, 2008).

O. gratissimum (lamiaceae), commonly known as "alfavaca" is naturally used in the treatment of different diseases for example upper respiratory tract infections (Ilori et al, 1996).

C. gariepinus is known to be omnivorous and due to its high quality, market potentials and acceptability among others is an economically important fish food in various countries (Babalola and Apata, 2006; Ibrahim et al., 2007; Wikipeadia, 2008). O. gratissimum has been researched on and is used as a natural antibiotic because of its antibacterial and antifungal properties. Thus this study seeks to determine the use of $O$. gratissimum in improving the haematological quality of $C$. gariepinus. 


\section{Materials AND Methods}

\subsection{Preparation of Experimental Leaf Meal}

Fresh leaves of O.gratissimum were collected, rinsed with clean water to remove any foreign matter, chopped and air-dried. The dried leaf of $O$. gratissimum was subjected to proximate analysis to ascertain the phyto-chemicals present in it. The dried leaves of $O$. gratissimum were milled in a nearby hammer mill. Grounded $O$. gratissimum was thoroughly mixed with $2 \mathrm{~mm}$ coppens fish feed at a rate of $0 \mathrm{~g}, 10 \mathrm{~g}, 20 \mathrm{~g}, 30 \mathrm{~g}$, and $40 \mathrm{~g}$ per $1 \mathrm{~kg}$ of feed and labeled as diets D1, D2, D3, D4 and D5 respectively. Diet D1 without $O$.gratissimum inclusion, was the control.

One hundred and fifty juveniles of $C$. gariepinus used for the study were acclimated in a $1 \mathrm{~m} \times 1 \mathrm{~m} \mathrm{x}$ $1 \mathrm{~m}$ concrete tank for one week before commencement of the experiment. During acclimation the fishes were fed to satiation with coppens feed twice daily.

\subsection{Experimental Design}

The design was a complete randomized block design (CRBD). Fish were randomly distributed in tens into 15 concrete outdoor tanks of $1 \mathrm{~m} \times 1 \mathrm{~m} \times 1 \mathrm{~m}$. Fish and tanks were grouped in threes, to form five treatments in triplicates labeled T1 - T5. Treatment 1 without O.gratissimum inclusion served as control. Fish in the Tanks were cultured for four (4) months and fed diets having the same numbers as the tanks. Rations fed were $3 \%$ body weight twice daily.

\subsection{Collection of Blood Samples}

At the end of the culture period, a fish sample was caught from each Tank and blood samples was collected for analysis in the laboratory. After the preliminary investigation of the length and weight of the fish, the fishes were placed on a tray and a towel was used to clean the body to avoid the mixture of blood and water. Blood samples were obtained from the caudal fin with the aid of a clinical disposable plastic syringe. The needle was inserted at right angle to the vertebral column of the fish and was gently aspirated during penetration. The needle was pushed gently down until blood started to enter as the needle. The blood was drawn gently until about $3 \mathrm{~cm}^{3}$ of blood was obtained.

Thereafter, the needle was withdrawn and the blood immediately transferred into a heparinized plastic tube. The sample was gently but thoroughly mixed to avoid coagulation. Blood samples were used for the measurement of haematocrit (Pack Cell Volume) haemoglobin concentration, red blood cell count, white blood cell count and plasma protein.

\subsection{Blood Analysis}

Data collected from the blood were used to determine

- Hemoglobin concentration

- Haematocrit (Packed Cell Volume)

- Plasma Protein

- The Red Blood Cell.

- White Blood Cell Count (WBC)

Data collected on blood parameters were subjected to Pearson's correlation matrix, Analysis of Variance and means were separated using New Duncan Multiple Range Test (NDMRT).

\section{RESUlts}

Table1. Proximate Analysis of Ocimum Gratissimum

\begin{tabular}{|l|l|l|l|l|l|}
\hline S/N & \multicolumn{1}{|c|}{ Parameters } & \multicolumn{1}{|c|}{ Conc(g/100g) } & Sh/N & \multicolumn{1}{c|}{ Status } \\
\hline 1 & Carbohydrates & 3.92 & 1 & Alkaloid & + \\
\hline 2 & Protein & 6.24 & 2 & Saponin & ++ \\
\hline 3 & Ash. & 1.98 & 3 & Tannin & + \\
\hline 4 & Crude fibre & 2.41 & 4 & Phlobatannins & + \\
\hline 5 & Crude lipids & 4.81 & 5 & Anthraquinone & + \\
\hline 6 & Energy & 83.16 & 6 & Steroids & + \\
\hline 7 & Sodium & 5.11 & 7 & Terpenoids & + \\
\hline 8 & Potassium & 0.98 & 8 & Flavonoids & + \\
\hline 9 & Calcium & 4.82 & 9 & Reducing sugar & +++ \\
\hline & & & 10 & Carotinoid & + \\
\hline
\end{tabular}

Note: Results are average of triplicate analysis, sample used in dried mass.

+ low concentration, ++ moderate concentration, +++ high concentration, - absent 
The result of the phytochemical screening in Table 1 revealed the presence of tannins, phlobatannins, anthraquinone, flavonoids, reducing sugar, terpenoids, steroids, saponins and alkaloids in $O$. gratissimum. In particular the flavonoids, saponins and anthraquinone were detected in high and moderate concentrations.

Table2. Mean Variation Of Blood Parameter Of Clarias Gariepinus Fed Graded Levels Ofocimum Gratissimum As Feed Additive.

\begin{tabular}{|l|l|l|l|l|l|}
\hline \multicolumn{7}{|c|}{ Treatment } \\
\hline \multicolumn{1}{|c|}{ Parameters } & \multicolumn{1}{|c|}{$\mathbf{0 g}(\mathbf{T 1})$} & \multicolumn{1}{|c|}{$\mathbf{1 0 g}(\mathbf{T 2})$} & \multicolumn{1}{c|}{$\mathbf{2 0 g}(\mathbf{T 3})$} & \multicolumn{1}{c|}{$\mathbf{3 0 g}(\mathbf{T 4})$} & \multicolumn{4}{c|}{$\mathbf{4 0 g}(\mathbf{T 5})$} \\
\hline RBC & $1.60 \pm 0.17^{\mathrm{d}}$ & $2.37 \pm 0.12^{\mathrm{a}}$ & $1.83 \pm 0.33^{\mathrm{b}}$ & $1.70 \pm 0.15^{\mathrm{c}}$ & $1.63 \pm 0.24^{\mathrm{c}}$ \\
\hline WBC & $1.33 \pm 0.15^{\mathrm{e}}$ & $4.63 \pm 1.85^{\mathrm{a}}$ & $3.33 \pm 1.14^{\mathrm{b}}$ & $2.77 \pm 2.51^{\mathrm{c}}$ & $1.97 \pm 0.38^{\mathrm{d}}$ \\
\hline P.P. & $7.20 \pm 0.37^{\mathrm{a}}$ & $7.27 \pm 0.61^{\mathrm{a}}$ & $7.13 \pm 0.41^{\mathrm{ab}}$ & $7.00 \pm 0.58^{\mathrm{b}}$ & $6.70 \pm 0.15^{\mathrm{c}}$ \\
\hline H.B & $11.10 \pm 0.61^{\mathrm{a}}$ & $8.83 \pm 0.49^{\mathrm{b}}$ & $8.83 \pm 0.49^{\mathrm{b}}$ & $7.87 \pm 0.47^{\mathrm{c}}$ & $6.60 \pm 0.61^{\mathrm{d}}$ \\
\hline PCV & $35.00 \pm 2.89^{\mathrm{a}}$ & $32.35 \pm 1.73^{\mathrm{a}}$ & $32.00 \pm 1.53^{\mathrm{ab}}$ & $26.00 \pm 1.53^{\mathrm{b}}$ & $22.33 \pm 1.45^{\mathrm{bc}}$ \\
\hline MCHC & $30.24 \pm 0.02^{\mathrm{b}}$ & $30.78 \pm 0.33^{\mathrm{a}}$ & $30.52 \pm 0.36^{\mathrm{a}}$ & $30.20 \pm 0.30^{\mathrm{b}}$ & $30.08 \pm 0.21^{\mathrm{bc}}$ \\
\hline MCH & $6.78 \pm 1.11^{\mathrm{a}}$ & $5.87 \pm 0.58^{\mathrm{b}}$ & $5.44 \pm 0.66^{\mathrm{bc}}$ & $4.79 \pm 0.75^{\mathrm{c}}$ & $2.84 \pm 0.30^{\mathrm{d}}$ \\
\hline MCV & $2.29 \pm 0.37^{\mathrm{a}}$ & $1.93 \pm 0.1^{\mathrm{b}}$ & $1.80 \pm 0.21^{\mathrm{bc}}$ & $1.71 \pm 0.29^{\mathrm{c}}$ & $1.52 \pm 0.25^{\mathrm{d}}$ \\
\hline
\end{tabular}

Means with the same superscript on the same row are not significantly different $(P>0.05)$. Where; $\pm=$ standard error of the mean, $P C V=$ Packed Cell Volume, Hb= Haemoglobin, PP=Plasma Protein, RBC $=$ Red Blood Cell , WBC = White Blood Cell, $M C H C=$ Mean Corpuscular Haemoglobin Concentration, $M C H=$ Mean Corpuscular Haemoglobin, MCV = Mean Corpuscular Volume.

Table 2 showed a decreasing trend in RBC count in all experimental groups, this decreasing trend is statistically significant $(\mathrm{P}<0.05)$. The highest mean value of $2.37+0.1210^{4} / \mathrm{ul}$ was observed in $\mathrm{T} 2$ while the lowest value was recorded for T1. Increase in inclusion level beyond $10 \%$, resulted in a decrease in RBC concentration. A similar observation was made for the WBC, PP and MCHC concentrations. The RBCs count shows significant decrease in T4 and T5 $(\mathrm{P}<0.01)$ when compared to T2. The T2 group has shown significant increase when compared to T3, T4 and T5 in mean value of WBCs count. Plasma protein count showed significant increase $(\mathrm{P}<0.05)$ in T2 compared to any other treatment except the control T1.The PCV in all experimental groups reported lower values than the control. The PCV value of the T2 and T3 did not vary much from the control (T1).The MCHC registered a higher value than that of control group for the experiment T2 $(30.78 \pm 0.33 \%)$ and for all other groups a decline is observed.

From Table 2 with the use of one-way ANOVA and Duncan Multiple Range Test to separate the means it shows that most of the parameters are statistically significant $(\mathrm{p}<0.05)$ in response to changes in different level of $O$. gratissimum inclusion in the feed.

In Treatment 1 , Table 3, WBC is positively correlated with $\mathrm{MCH}$ but not significantly related to other blood parameters, $\mathrm{HB}$ is also positively correlated with $\mathrm{MCV}, \mathrm{MCH}$ is positively correlated to $\mathrm{WBC}$, $\mathrm{MCV}$ is also positively correlated to HB. All correlations are related significantly at a level of $(\mathrm{r}=0.55$, $\mathrm{p}<0.05)$

Table3. Pearson's Correlation matrix for the haematological profile of $C$. gariepinus fed $0 \mathrm{~g}$ O.gratissimum inclusion in Diet 1

\begin{tabular}{|c|c|c|c|c|c|c|c|c|c|}
\hline \multicolumn{10}{|c|}{ Correlations } \\
\hline \multicolumn{2}{|c|}{ Treatment } & RBC & WBC & $\mathrm{PP}$ & $\mathrm{HB}$ & PCV & $\mathrm{MCHC}$ & $\mathrm{MCH}$ & $\mathrm{MCV}$ \\
\hline \multirow[t]{4}{*}{$\mathrm{RBC}$} & Pearson & 1 & .932 & .812 & .985 & .264 & .123 & .928 & .973 \\
\hline & Correlation & & .237 & .397 & .111 & .830 & .921 & .243 & .149 \\
\hline & Sig. (2-tailed) & & 3 & 3 & 3 & 3 & 3 & 3 & 3 \\
\hline & $\mathrm{N}$ & & 1 & .968 & .981 & .596 & .475 & $1.000 *$ & .991 \\
\hline \multirow[t]{4}{*}{ WBC } & Pearson & & & .161 & .126 & .593 & .685 & .006 & .088 \\
\hline & Correlation & & & 3 & 3 & 3 & 3 & 3 & 3 \\
\hline & Sig. (2-tailed) & & & 1 & .901 & .778 & .680 & .971 & .925 \\
\hline & & & & & .286 & .433 & .524 & .155 & .248 \\
\hline \multirow[t]{4}{*}{ PP } & Pearson & & & & 3 & 3 & 3 & 3 & 3 \\
\hline & Correlation & & & & 1 & -427 & .294 & .979 & .998 \\
\hline & Sig. (2-tailed) & & & & & .719 & .810 & .132 & .038 \\
\hline & & & & & & 3 & 3 & 3 & 3 \\
\hline \multirow[t]{4}{*}{$\mathrm{HB}$} & Pearson & & & & & 1 & .990 & .064 & .480 \\
\hline & Correlation & & & & & & .091 & .587 & .681 \\
\hline & Sig. (2-tailed) & & & & & & 3 & 3 & 3 \\
\hline & & & & & & & 1 & .484 & .350 \\
\hline PCV & Pearson & & & & & & & .679 & .772 \\
\hline
\end{tabular}




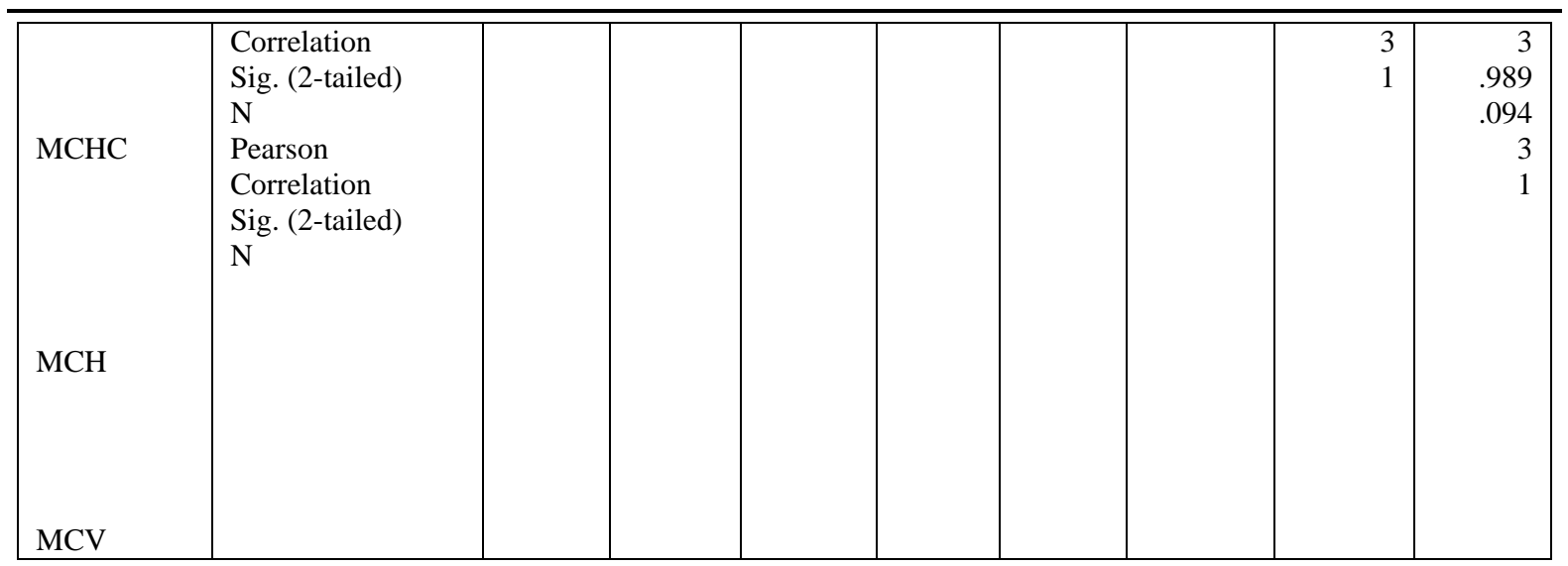

*. Correlation is significant at the 0.05 level (2-tailed).

**. Correlation is significant at the 0.01 level (2-tailed).

$P C V=$ Packed Cell Volume, Hb= Haemoglobin, $P P=$ Plasma Protein, $R B C=$ Red Blood Cell, WBC $=$ White Blood Cell, MCHC=Mean Corpuscular Haemoglobin Concentration, MCH = Mean Corpuscular Haemoglobin, $M C V=$ Mean Corpuscular Volume.

RBC had a positive correlation with WBC and PP $(r=0.55, \mathrm{p}<0.05)$ for $\mathrm{T} 2$ but was not significantly related to the other blood parameters (Table 3 ). WBC is positively correlated with RBC and PP $(\mathrm{r}=0.55, \mathrm{p}<0.05)$ but was not significantly related to the other blood parameters. PP is positively correlated with $\mathrm{RBC}$ and $\mathrm{WBC}^{*}(\mathrm{r}=0.55, \mathrm{p}<0.05)$ for $\mathrm{T} 2$ but was not significantly related to the other blood parameters. HB had no correlation with the other blood parameters. PCV was not significantly related to the other blood parameters. MCHC was not significantly related to the other blood parameters. $\mathrm{MCH}$ had a positive correlation with $\mathrm{MCV}(\mathrm{r}=0.55, \mathrm{p}<0.05)$ but was not significantly related to the other blood parameters. $\mathrm{MCV}$ is positively related to $\mathrm{MCH}(\mathrm{r}=0.55, \mathrm{p}<0.05)$ but was not significantly related to the other blood parameters.

Table4.Pearson's Correlation matrix for the haematological profile ofClariasgariepinus fed $10 g(T 2)$ Ocimum gratissimum

\begin{tabular}{|c|c|c|c|c|c|c|c|c|c|}
\hline \multicolumn{10}{|c|}{ Correlations } \\
\hline \multicolumn{2}{|c|}{ Treatment } & RBC & WBC & $\mathrm{PP}$ & $\mathrm{HB}$ & $\mathrm{PCV}$ & $\mathrm{MCHC}$ & $\mathrm{MCH}$ & $\mathrm{MCV}$ \\
\hline \multirow[t]{4}{*}{ RBC } & Pearson & 1 & $.999^{*}$ & $1.000 *$ & .529 & .500 & .022 & .948 & .942 \\
\hline & Correlation & & .023 & .017 & .645 & .667 & .989 & .205 & .219 \\
\hline & Sig. (2-tailed) & & 3 & & 3 & 3 & 3 & 3 & 3 \\
\hline & & & 1 & $.998^{*}$ & .559 & .468 & -.014 & .959 & .953 \\
\hline \multirow[t]{4}{*}{ WBC } & Pearson & & & .040 & .622 & .690 & .991 & .182 & .196 \\
\hline & Correlation & & & 3 & 3 & 3 & 3 & 3 & 3 \\
\hline & Sig. (2-tailed) & & & 1 & .506 & .524 & .050 & .939 & .932 \\
\hline & $\mathrm{N}$ & & & & .663 & .649 & .968 & .223 & .236 \\
\hline \multirow[t]{4}{*}{ PP } & Pearson & & & & 3 & 3 & 3 & 3 & 3 \\
\hline & Correlation & & & & 1 & -470 & -.837 & .771 & .784 \\
\hline & Sig. (2-tailed) & & & & & 688 & .369 & .440 & .427 \\
\hline & & & & & & 3 & 3 & 3 & 3 \\
\hline \multirow[t]{4}{*}{ HB } & Pearson & & & & & 1 & .877 & .200 & .179 \\
\hline & Correlation & & & & & & .319 & .872 & .885 \\
\hline & Sig. (2-tailed) & & & & & & 3 & & 3 \\
\hline & & & & & & & 1 & -.296 & -.316 \\
\hline \multirow[t]{4}{*}{ PCV } & Pearson & & & & & & & .809 & .796 \\
\hline & Correlation & & & & & & & 3 & 3 \\
\hline & Sig. (2-tailed) & & & & & & & 1 & $1.000^{*}$ \\
\hline & & & & & & & & & .013 \\
\hline \multirow[t]{3}{*}{$\mathrm{MCHC}$} & Pearson & & & & & & & & 3 \\
\hline & Correlation & & & & & & & & 1 \\
\hline & $\begin{array}{l}\text { Sig. (2-tailed) } \\
\mathrm{N}\end{array}$ & & & & & & & & \\
\hline \multirow{2}{*}{\multicolumn{10}{|c|}{$\mathrm{MCH}$}} \\
\hline $1 \mathrm{VICH}$ & & & & & & & & & \\
\hline $\mathrm{MCV}$ & & & & & & & & & \\
\hline
\end{tabular}


*. Correlation is significant at the 0.05 level (2-tailed).

**. Correlation is significant at the 0.01 level (2-tailed).

$P C V=$ Packed Cell Volume, Hb= Haemoglobin, PP= Plasma Protein, RBC = Red Blood Cell, WBC=White Blood Cell, $M C H C=$ Mean Corpuscular Haemoglobin Concentration, $M C H=$ Mean Corpuscular Haemoglobin, MCV = Mean Corpuscular Volume.

For $\mathrm{T} 3$, there was no correlation between $\mathrm{RBC}$ and the other blood parameters. There was also no correlation amongst WBC ,PP ,HB ,PCV and any other blood parameter. MCHC was positively related to $\mathrm{MCV}(\mathrm{r}=0.55, \mathrm{p}<0.05)$ and $\mathrm{MCV}$ is also positively related to $\mathrm{MCHC}(\mathrm{r}=0.55, \mathrm{p}<0.05)$.

Table5. Pearson's Correlation matrix for the haematological profile of Clarias gariepinus fed 20g (T3) Ocimum gratissimum

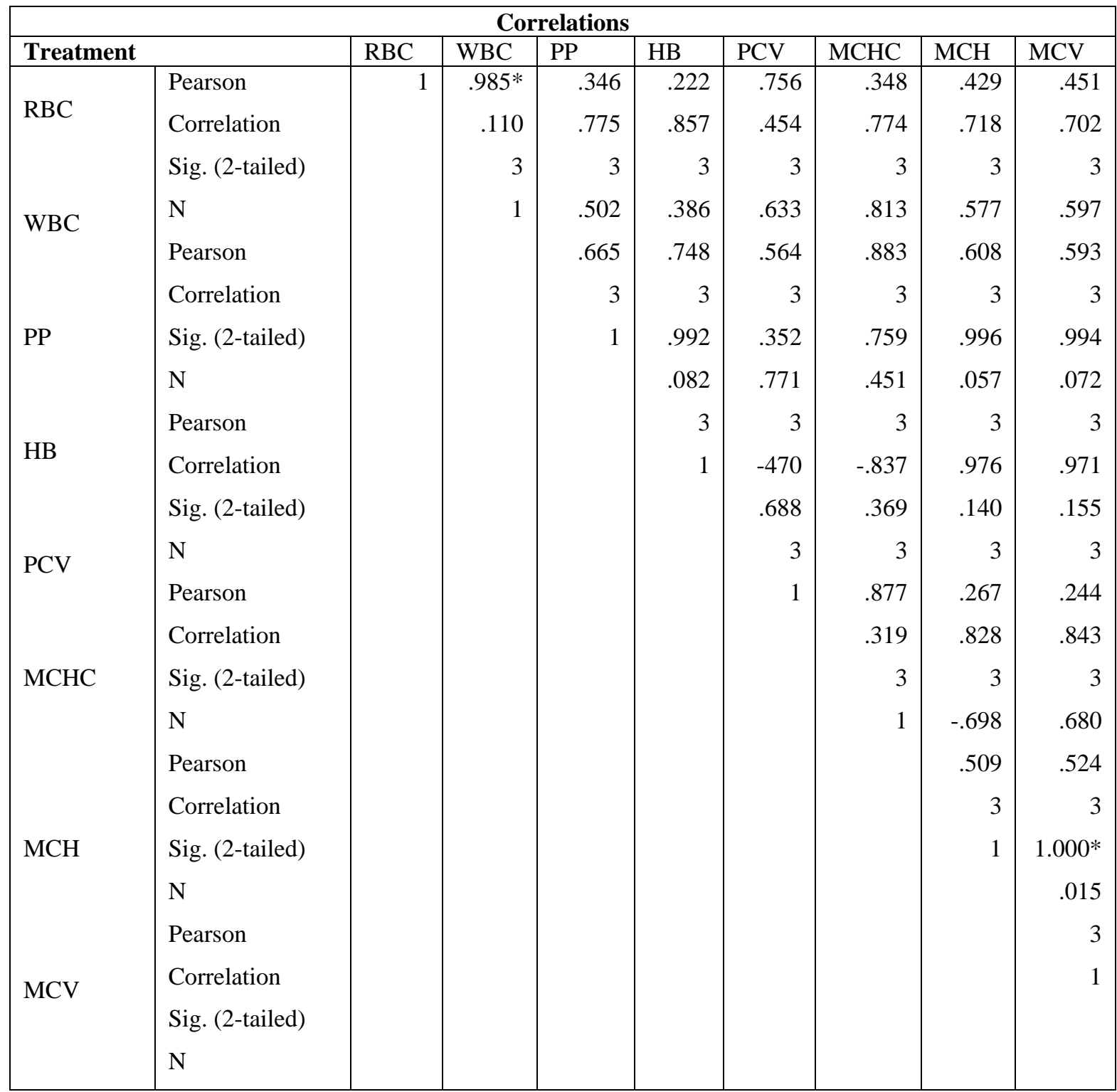

*. Correlation is significant at the 0.05 level (2-tailed).

*. Correlation is significant at the 0.01 level (2-tailed).

$P C V=$ Packed Cell Volume, Hb= Haemoglobin, PP= Plasma Protein, RBC = Red Blood Cell, WBC=White Blood Cell, $\mathrm{MCHC}=$ Mean Corpuscular Haemoglobin Concentration, $\mathrm{MCH}=$ Mean Corpuscular Haemoglobin, MCV = Mean Corpuscular Volume.

For T4, all blood parameters were not positively related to each other except for PP and MCV that were positively related to each other $(\mathrm{r}=0.55, \mathrm{p}<0.05)$ but was not significantly related to the other blood parameters (Table 6) 
Table6. Pearson's Correlation matrix for the haematological profile of Clarias gariepinus fed 30g(T4) Ocimum gratissimum

\begin{tabular}{|c|c|c|c|c|c|c|c|c|c|}
\hline \multicolumn{10}{|c|}{ Correlations } \\
\hline \multicolumn{2}{|c|}{ TREATMENT } & RBC & WBC & $\mathrm{PP}$ & $\mathrm{HB}$ & $\mathrm{PCV}$ & $\mathrm{MCHC}$ & $\mathrm{MCH}$ & $\mathrm{MCV}$ \\
\hline \multirow[t]{4}{*}{$\mathrm{RBC}$} & Pearson & 1 & .910 & .961 & .661 & .795 & -.238 & .950 & .969 \\
\hline & Correlation & & .272 & .179 & .540 & .415 & .847 & .203 & .156 \\
\hline & Sig. (2-tailed) & & 3 & 3 & 3 & 3 & 3 & 3 & 3 \\
\hline & $\mathrm{N}$ & & 1 & .989 & .290 & .472 & .186 & .734 & .984 \\
\hline \multirow[t]{4}{*}{ WBC } & Pearson & & & .093 & .812 & 687 & .881 & .475 & .114 \\
\hline & Correlation & & & 3 & 3 & 3 & 3 & 3 & 3 \\
\hline & Sig. (2-tailed) & & & 1 & .472 & .596 & .040 & .826 & $.999 *$ \\
\hline & & & & & .719 & .593 & .974 & .382 & .021 \\
\hline \multirow[t]{4}{*}{ PP } & Pearson & & & & 3 & 3 & 3 & 3 & 3 \\
\hline & Correlation & & & & 1 & .981 & -.886 & .863 & .457 \\
\hline & Sig. (2-tailed) & & & & & .126 & .307 & .337 & .698 \\
\hline & & & & & & 3 & 3 & 3 & 3 \\
\hline \multirow[t]{4}{*}{$\mathrm{HB}$} & Pearson & & & & & 1 & .778 & .945 & .622 \\
\hline & Correlation & & & & & & .432 & .212 & .572 \\
\hline & Sig. (2-tailed) & & & & & & 3 & 3 & 3 \\
\hline & & & & & & & 1 & -.531 & .007 \\
\hline \multirow[t]{3}{*}{ PCV } & Pearson & & & & & & & .644 & .995 \\
\hline & Correlation & & & & & & & 3 & \\
\hline & Sig. (2-tailed) & & & & & & & 1 & .844 \\
\hline \multirow[t]{3}{*}{$\mathrm{MCHC}$} & Pearson & & & & & & & & $\begin{array}{r}.361 \\
3\end{array}$ \\
\hline & Correlation & & & & & & & & 1 \\
\hline & $\begin{array}{l}\text { Sig. (2-tailed) } \\
\mathrm{N}\end{array}$ & & & & & & & & \\
\hline \multicolumn{10}{|l|}{$\mathrm{MCH}$} \\
\hline $\mathrm{MCV}$ & & & & & & & & & \\
\hline
\end{tabular}

*. Correlation is significant at the 0.05 level (2-tailed).

**. Correlation is significant at the 0.01 level (2-tailed).

$P C V=$ Packed Cell Volume, Hb= Haemoglobin, $P P=$ Plasma Protein, $R B C=$ Red Blood Cell, WBC=White Blood Cell, MCHC=Mean Corpuscular Haemoglobin Concentration, MCH = Mean Corpuscular Haemoglobin, $M C V=$ Mean Corpuscular Volume.

For T5, Table 7, RBC had a positive relationship with PCV. WBC had a positive correlation with $\mathrm{MCH}$. HB is positively correlated with PCV. PCV is positively correlated with RBC and HB. MCH is positively correlated with WBC. All correlations are significantly related at $(\mathrm{r}=0.55, \mathrm{p}<0.05)$.

Table7. Pearson's Correlation matrix for the haematological profile of Clarias gariepinus fed 40g(T5) Ocimum gratissimum

\begin{tabular}{|c|c|c|c|c|c|c|c|c|c|}
\hline \multicolumn{10}{|c|}{ Correlations } \\
\hline \multicolumn{2}{|c|}{ TREATMENT } & RBC & WBC & $\mathrm{PP}$ & $\mathrm{HB}$ & $\mathrm{PCV}$ & $\mathrm{MCHC}$ & $\mathrm{MCH}$ & $\mathrm{MCV}$ \\
\hline \multirow[t]{4}{*}{$\mathrm{RBC}$} & Pearson & 1 & .948 & .908 & .993 & .999 & -.355 & .958 & .693 \\
\hline & Correlation & & .207 & .275 & .076 & .033 & .769 & .185 & .512 \\
\hline & Sig. (2-tailed) & & 3 & 3 & 3 & 3 & 3 & 3 & 3 \\
\hline & & & 1 & .726 & .903 & .929 & .038 & $.999 *$ & .887 \\
\hline \multirow{4}{*}{ WBC } & Pearson & & & 483 & 283 & 241 & 976 & .023 & .305 \\
\hline & Correlation & & & 3 & 3 & 3 & 3 & 3 & 3 \\
\hline & Sig. (2-tailed) & & & 1 & 951 & 929 & .715 & .750 & .327 \\
\hline & & & & & 199 & .242 & 493 & 460 & .788 \\
\hline \multirow[t]{4}{*}{ PP } & Pearson & & & & 3 & 3 & 3 & 3 & 3 \\
\hline & Correlation & & & & 1 & -998 & -.464 & .917 & .603 \\
\hline & Sig. (2-tailed) & & & & & .043 & .693 & .261 & .588 \\
\hline & & & & & & 3 & 3 & 3 & 3 \\
\hline \multirow[t]{4}{*}{$\mathrm{HB}$} & Pearson & & & & & 1 & -.404 & .942 & .655 \\
\hline & Correlation & & & & & & .735 & .218 & .546 \\
\hline & Sig. (2-tailed) & & & & & & 3 & $\begin{array}{r}3 \\
-073\end{array}$ & $\begin{array}{r}3 \\
427\end{array}$ \\
\hline & $\mathrm{N}$ & & & & & & 1 & -.073 & .427 \\
\hline
\end{tabular}


Studies of the Effect on the Haematology and Immuno-System of Clarias gariepinus Fed Graded Levels of Ocimum gratissmum as Feed Additive

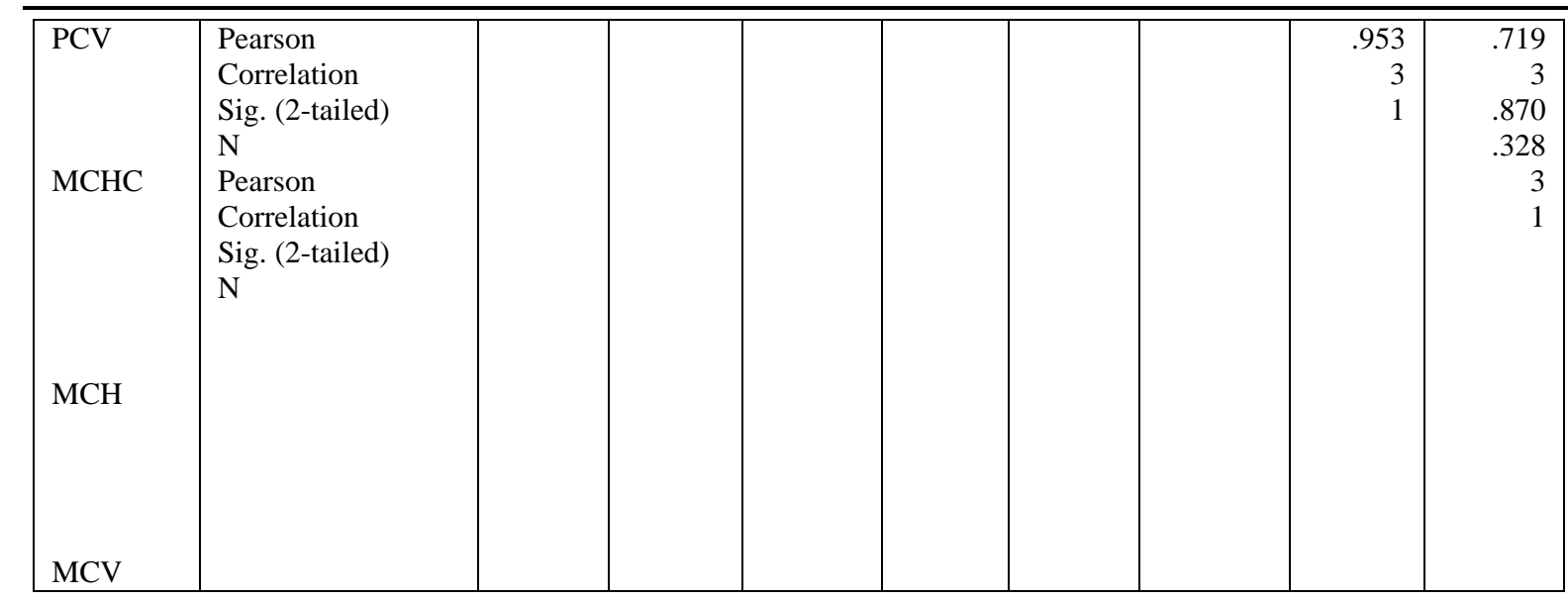

*. Correlation is significant at the 0.05 level (2-tailed).

*. Correlation is significant at the 0.01 level (2-tailed).

$P C V=$ Packed Cell Volume, Hb= Haemoglobin, PP= Plasma Protein, RBC $=$ Red Blood Cell, $W B C=$ White Blood Cell, $M C H C=$ Mean Corpuscular Haemoglobin Concentration, $M C H=$ Mean Corpuscular Haemoglobin, $M C V=$ Mean Corpuscular Volume.

\section{DisCUSSION}

There is a high value for RBC in treatments $\mathrm{T} 2$ to $\mathrm{T} 5$ when compared with $\mathrm{T} 1(0 \mathrm{~g})$. This result is supported by Sahu et al. (2007) who reported that Red Blood Cells count were higher in Labeo rohita fingerlings fed Magnifera indica kernel and they postulated that this increase is an indication of enhanced cellular immunity. This increase in Red Blood Cells values in the treated groups, may be because of the possible mechanism by which the Ocimum gratissimum extract may have triggered erythropoiesis and also decrease the rate of oxidant induced haemolysis, due to the presence of the antioxidants present in the plant extract as reported by Sheeja et al. (2006). Contrary to the result of this study, the administration of O.gratissimumto rats did not have any significant effect on RBC, $\mathrm{PCV}, \mathrm{Hb}, \mathrm{MCV}, \mathrm{MCH}$ and MCHC as reported by Okon et al. (2011).

In this study, with the inclusion of Ocimum gratissimum to the diet of $C$. gariepinus, there was a significant increase in total White Blood Cell count for T2-T5. Similar results were obtained by Sahu et al. (2007) when L. rohita was fed with Magnifera indica kermel and by Dada and Ikuerowo (2009) who studied the effect of ethanolic extract of G. cambogia in catfish, C. gariepinus brood stock. Contrary to the reports of Ephraim et al. (2000) and Jimoh et al. (2008), the White Blood Cell count level significantly increased in the test groups when compared to the control group. On the basis of the present study, the increase neutrophil (White Blood Cell) level reemphasizes its anti-bacterial and anti-fungal properties and justifies the use of the plant by traditional medicine practitioners; considering that neutrophils constitute the first line of defense.

The blood indices such as Mean Corpuscular Volume (MCV), Mean Corpuscular Haemoglobin $(\mathrm{MCH})$ and Mean Corpuscular Haemoglobin Concentration (MCHC), are particularly important for the diagnosis of anemia in most animals. In this study, the Mean Corpuscular Volume (MCV) and Mean Corpuscular Haemoglobin $(\mathrm{MCH})$ values decreased in all the other treatments (T2-T5) compared with the control. This could be the reason for the high mortality rate observed in T4 (with the highest amount of Ocimum gratissimum inclusion of $40 \mathrm{~g} / \mathrm{Kg}$ of feed) and lowest values of MCV and $\mathrm{MCH}$. Mean Corpuscular Haemoglobin Concentration (MCHC) maintained a steady value in all experimental groups. The maintenance of constant level or increase of Mean Corpuscular Haemoglobin Concentration (MCHC) in Clarias gariepinus fed Ocimum gratissimum as feed additive, may bring an improvement in fish health as suggested by Suresh and Amoikumar (2009).

Obaji et al. (2005) had reported a generalized anti-haematinic effect of $O$. gratissimum and cautioned on the adverse consequences of its prolonged use. It is possible that $O$. gratissimum could induce haemolysis and can even suppress haemopoiesis because of its phytochemical constituent, such as saponin. However the detaiedl specific mechanism of action is not clear. Nevertheless, it appears that the anti-haematinic effect of saponins to some extent could be cell linage selective. There is also a possibility that other constituents of $O$. gratissimum could stimulate the activity of some haemopoietic 
growth factors while inhibiting others. It is therefore possible that some of the active ingredients in $O$. gratissimum could promote the action of growth factors related to neutrophil production, while at the same time inhibiting growth factors associated with platelets and lymphocytes production.

\section{Conclusion}

In conclusion, the optimum level of inclusion of Ocimum gratissimum to C. gariepinus is $10 \mathrm{~g} / \mathrm{kg}$ of diet. The haematological profile of C. gariepinus fed $10 \mathrm{~g} / \mathrm{kg}$ inclusion of Ocimum gratissimum performed better with an increase in RBC, WBC, PP and MCHC. Therefore, it can be concluded that an inclusion of $10 \mathrm{~g} / \mathrm{kg}$ of Ocimum gratissimum in the diet of Clarias gariepinus will yield optimum results for better immunity, growth and survival under culture conditions.

\section{REFERENCES}

[1] Dada, A.A. and,Ikuerowo,M.,(2009). Effects of ethanolic extracts of garciniakolaseeds on growth and haematology of catfish (Clariasgariepinus) Broodstock. African J. agri. Res .,4:344347.

[2] Dada, B.F. and D.A.S. Gnanadoss, (1983).Nigeria Statistical fisheries development challenges and opportunities F.I.S.O.N. Conference paper, pp: 14.

[3] Effrain, I. O., Salami, H. A. and Osewa, T. S. (2000). The Effect of Aqueous Leaf Extract of Ocimumgratissimumon Haematological and Biochemical Parameters InRabbits.Afri. J. Biomed Res. $175-179$.

[4] FAO, (2004).World Aquaculture supply of catfish and tilapia. FAO fisheries $\quad$ report $\quad$ No 733 FAO Rome, pp: 46.

[5] FAO., (2003). Opportunities for aquaculture development in Nigeria, FAO Aquaculture Newsletter No 29. FAO, Rome, pp: 39.

[6] Ilori, M, Sheteolu, A. O., Omonigbehin, E. A., Adeneye, A. A. (1996). Antibacterial Activity of Ocimumgratissimum(Lamiaceae).J. Diarhoeal Dis. Res. 14: 283-285

[7] Obagi C, et al. (2005) Regulation of neurite outgrowth in NIE-115 cells through PZDmediated recruitment of diacylglycerol kinase zeta. Mol Cell Biol. pp 7289-7302

[8] Okigbo, R. N. and Igwe, M. 2007. The Antimicrobial Effects of Piper Guineenseuzizaand Phyllantusamarusebe-benizo on Candida albicansand Streptococcus FaecalisActa Microbiological et. ImmonologicaHungarica 54(4): 353 - 366.

[9] Sahu, S., Basanta, K.D., Pradhan, J., Mohapatra, B.C., Mistra, B.K., Sarangi, ～N.(2007). Effect of Magniferaindica kernel as a feed additive on immunity and resistance to Aeromonashydrophila in Labeorohita fingerlings.Fish and shellfish immunology, 23(1): 109-118.

[10] Sheeja., K. Shihab .P.K. and kuttan.G.,(2006). Antioxidant and anti-inflammatory activities of the plant andrographispaniculata NEES.J. Immonopharmacologyimmunotoxicology, 28(1):129140

[11] Suresh, R.N,.andAmolkumar,H.(2009). Evaluation of immunomodulatory activityof an extract of and andrographalidespariculata.Thiemee .J.Planta Med., 75(8):785-79

\section{Authors' BIOGRAPHY}

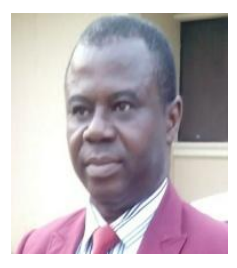

EKELEMU Jerimoth Kesena, holds a B.Sc , M.Sc and Ph.D degree in Fish Biology, Hydrobiology and Fisheries/Limnology respectively. He is currently an Associate Professor of Fisheries/Limnology in the Department of Fisheries/Aquaculture Technology in Delta State University, Abraka Nigeria.

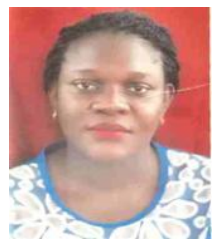

MARROH Eseoghene, holds a B. Fisheries degree from Delta State University, Abraka Nigeria. She is currently pursuing a Master of Science degree in fisheries from the same University. 